\title{
IMPLEMENTASI MODEL PEMBELAJARAN DIRECT LEARNING PADA MATA PELAJARAN BAHASA INDONESIA MATERI MENULIS CERITA GUNA MENINGKATKAN MINAT BELAJAR SISWA KELAS II SD N 3 KARANGRAJA
}

\author{
Ponidi $^{1)}$, Marilin Kristina ${ }^{2)}$ \\ STMIK Pringsewu Lampung \\ oniponidi@yahoo.com ${ }^{1)}$, marilin_kristina@yahoo.com ${ }^{2)}$
}

\begin{abstract}
Abstrak
Rendahnya minat siswa terhadap pelajaran Bahasa Indonesia menyebabkan sebagian besar siswa kurang antusias mengikuti pelajaran yang disampaikan oleh guru, sehingga hasil belajar siswa rendah. Dengan kondisi tersebut guru berusaha memperbaiki pembelajaran dengan melaksanakan Penelitian Tindakan Kelas. Tujuan penelitian ini adalah untuk meningkatkan minat dan hasil belajar siswa pada mata pelajaran Bahasa Indonesia, materi pokok menulis cerita melalui pembelajaran Direct Learning di kelas II SDN 3 Karangraja. Subjek penelitian ini adalah siswa kelas II SDN 3 Karangraja, yang berjumlah 25 siswa. Metode yang digunakan dalam perbaikan pembelajaran ini adalah metode Direct Learning. Data yang diperoleh melalui hasil evaluasi siswa dan pengamatan oleh observer. Penelitian ini dilaksanakan selama dua siklus. Hasil penelitian menunjukkan bahwa setiap siklus ada kemajuan terbukti pada siklus pertama minat peserta didik mencapai 13 siswa (52,00\%) dalam pembelajaran dan peserta didik yang tuntas belajar pada perbaikan siklus I baru 13 siswa (52,0\%). Pada perbaikan siklus II terjadi peningkatan minat yaitu sebanyak 23 peserta didik (92,00\%)). sedangkan hasil belajar peserta didik semakin meningkat dengan ketuntasan belajar mencapai 23 siswa (92,0\%). Hal ini membuktikan bahwa melalui metode Direct Learning siswa dapat memecahkan permasalahan sendiri dalam pelajaran Bahasa Indonesia, materi pokok menulis cerita, sehingga hasil belajar siswa meningkat. Kesimpulan melalui hasil penelitian ini menunjukkan bahwa metode Direct Learning dapat meningkatkan minta dan hasil belajar siswa.
\end{abstract}

Kata Kunci : Minat Belajar, Metode Direct Learning, Menulis erita , Bahasa Indonesia.

\section{Latara Belakang Masalah}

Pendidikan dasar merupakan jenjang awal pendidikan sekolah yang memberikan dasar pembentukan pribadi manusia sebagai warga Negara. Lembaga pendidikan ini seyogyanya dapat membekali siswanya dengan berbagai nilai, sikap, serta kemampuan dan keterampilan dasar yang cukup kuat sebagai landasan untuk menyelesaikan pendidikan pada jenjang berikutnya.

Keterampilan dasar yang mutlak harus dimiliki oleh setiap siswa adalah keterampilan berbahasa Indonesia. Keterampilan berbahasa Indonesia tersebut siswa dapat memiliki ilmu serta dapat mengembangkan diri menjadi warga yang lebih baik. Begitu pula di 
lingkungan SD Negeri 3 Karangraja siswa lebih sering dan mengerti dengan bahasa keseharian atau pergaulan di lingkungan sekitar. Pada tahap pembelajaran bahasa ini pula mereka pertama mengenali serta memahami lingkungan sekitarnya, menyerap serta menerapkan berbagai nilai yang berlaku dalam lingkungannya. Dalam kaitan ini sangat penting arti pendidikan Bahasa Indonesia di Sekolah Dasar, karena melalui pendidikan tersebut diupayakan proses pembudayaan Bahasa Indonesia pada anak-anak yang lahir sebagai insan daerah.

Sesuai dengan kenyataan yang terjadi pada saat ini, mata pelajaran bahasa Indonesia sering diremehkan oleh sebagian besar siswa, bahkan dianggap sebagai pelajaran yang membosankan, khususnya dalam aspek menulis. Pada tahap dunia pendidikan, menulis merupakan suatu tuntutan keterampilan yang harus dikuasai oleh manusia sebagai bahasa tulis.

Mengingat pentingnya menulis bagi siswa, guru semestinya bisa membangkitkan kegairahan siswa untuk menulis serta menjadikan menulis itu merupakan pekerjaan yang alami dan menyenangkan. Langkah utama yang bisa ditempuh adalah dengan memilih dan menggunakan metode dan media pembelajaran yang tepat dan variatif yaitu dengan menggunakan media visual yang dapat membantu mengatasi keterbatasan ruang, waktu dan daya indera.

Di SD Negeri 3 Karang Raja sering mendapatkan kesulitan sehingga siswa dalam menulis hal ini dapat terlihat ketika disuruh membuat karangan sederhana, mendeskripsikan suatu benda ataupun ketika menulis cerita, mereka sering mengeluh dan terlihat bingung dengan apa yang mereka tulis.

Berdasarkan hal tersebut maka peneliti meminta bantuan kepada teman sejawat untuk membantu mengidentifikasi kekurangan dari pembelajaran yang dilaksanakan. Dari hasil diskusi ada beberapa masalah yang dihadapi dalam pembelajaran yang meliputi: (1) Kurangnya motivasi dan minat siswa terhadap kegiatan menulis; (2) Pengembangan strategi pembelajaran yang kurang membangkitkan daya imajinasi siswa dalam bahasa maupun bersastra; (3) Media pembelajaran yang digunakan kurang sesuai sehingga siswa kurang bersemangat dalam belajar

Berdasarkan dari identifikasi masalah peneliti melakukan refleksi 
diri dan diskusi dengan teman sejawat, dapat di ketahui bahwa kemungkinan faktor penyebab rendahnya tingkat penguasaan siswa terhadap materi pembelajaran dan rendahnya keaktifan serta perhatian siswa dalam proses pembelajaran adalah.

\section{Memperhatikan}

kendala

tersebut penulis mengadakan penelitian tindakan kelas untuk mengatasi masalah yang terjadi, dengan melakukan pembelajaran menggunakan model direct learning. Pengunaan model direct learning diharapkan akan mempermudah dalam memahami dan memperdalam keterampilan menulis cerita untuk meningkatkan motivasi belajar siswa sehingga dapat meningkatkan hasil belajar pada siswa kelas II SD Negeri 3 Karangraja.

\section{METODE PENELITIAN}
Penelitian ini menggunakan metode deskriptif kuantitaif. Pada penelitian diskriptif kuantitatif, peneliti berusaha menggambarkan kegiatan penelitian yang dilakukan pada objek tertentu secara jelas dan sistematis (Sukardi, 2004: 14). Penelitian deskriptif bertujuan untuk memberikan gambaran tentang suatu hubungan antara dua gejala atau lebih (Irawan Soehartono, 2008: 35).

Metode pengumpulan data dilakukan dengan cara :

a. Dokumentasi

Metode dokumentasi yaitu mencari data mengenai berbagai hal yang menyangkut catatan, trankrip, majalah, notulen rapat, agenda, catatan nilai dan sebagainya. Dalam penelitian ini metode dokumentasi diambil dari catatan harian pembelajaran, catatan kolaborator (mitra penelitian), nilai siswa, maupun catatan perkembangan siswa dalam proses pembelajaran.

b. Observasi

Observasi yaitu pengamatan dengan menggunakan indera penglihatan. Metode observasi adalah cara-cara menganalisis dan mengadakan pencatatan secara sistematis mengenai tingkah laku dengan melihat atau mengamati individu atau kelompok secara langsung. Metode ini digunakan untuk melihat dan mengamati secara langsung keadaan di lapangan agar peneliti memperoleh gambaran yang lebih luas tentang permasalahan yang diteliti (Irawan Soehartono, 2008: 69).

Metode observasi dilaksanakan dengan cara melihat kegiatan belajar mengajar secara langsung yang berhubungan dengan penelitian. Observasi dilaksanakan di 
lingkungan sekolah pada saat pembelajaran Pendidikan Bahasa Indonesia dilaksanakan. Observasi sangat membantu untuk dapat mempelajari perkembangan aktivitas siswa dan keterlibatan dalam proses pembelajaran Pendidikan Bahasa Indonesia

c. Tes

Metode tes digunakan untuk mengukur kemampuan siswa dalam menguasai materi pelajaran yang telah diberikan oleh guru. Metode tes dalam penelitian ini diberikan secara bertahap, setelah siswa mengikuti metode-metode pengajaran yang disampaikan oleh guru yang bersangkutan.

\section{ANALISIS DATA}

Data-data yang diperlukan dalam penelitian ini diperoleh melalui observasi pengolahan metode pembelajaran diskusi, observasi aktivitas siswa dan guru, dan tes formatif.

Guna mengetahui keefektifan
suatu metode dalam kegiatan
pembelajaran perlu diadakan analisa data. Pada penelitian ini menggunakan teknik analisis deskriptif kuantitatif, yaitu suatu metode penelitian yang bersifat menggambarkan kenyataan atau fakta sesuai dengan data yang diperoleh dengan tujuan untuk mengetahui prestasi belajar yang dicapai siswa juga untuk memperoleh respon siswa terhadap kegiatan pembelajaran serta aktivitas siswa selama proses pembelajaran.

Tingkat keberhasilan atau persentase keberhasilan siswa setelah proses belajar mengajar setiap putarannya dilakukan dengan cara memberikan evaluasi berupa soal tes tertulis pada setiap akhir putaran.

Analisis ini dihitung dengan menggunakan statistik sederhana yaitu Ketuntasan belajar berdasarkan kurikulum tingkat satuan pendidikan (KTSP). Siswa dinyatakan tuntas belajar bila telah mencapai hasil/ nilai sesuai KKM 68 untuk mata pelajaran bahasa Indonesia. Dinyatakan tuntas belajar bila dikelas tersebut telah mencapai $75 \%$ dari KKM. Guna menghitung prosentase ketuntasan belajar digunakan rumus sebagai berikut :

$\frac{\text { jumlah siswa yang tuntas }}{\text { jumlah total siswa }}$ x $100 \%$

Hasil perhitungan dikonsultasikan dengan Kriteria Ketuntasan Minimal (KKM) belajar yang dikelompokkan kedalam 2 kategori yaitu tuntas dan tidak tuntas sebagai berikut: 
Tabel 3.2

\section{Kriteria Ketuntasan Minimal Belajar}

\begin{tabular}{|c|l|}
\hline $\begin{array}{l}\text { Kriteria } \\
\text { ketuntasan }\end{array}$ & Kualifikasi \\
\hline$\geq 68$ & Tuntas \\
\hline$<68$ & Tidak Tuntas \\
\hline
\end{tabular}

(Depdikbud. 2007: 11)

Desain Prosedur Perbaikan

Pembelajaran Penelitian Tindakan Kelas

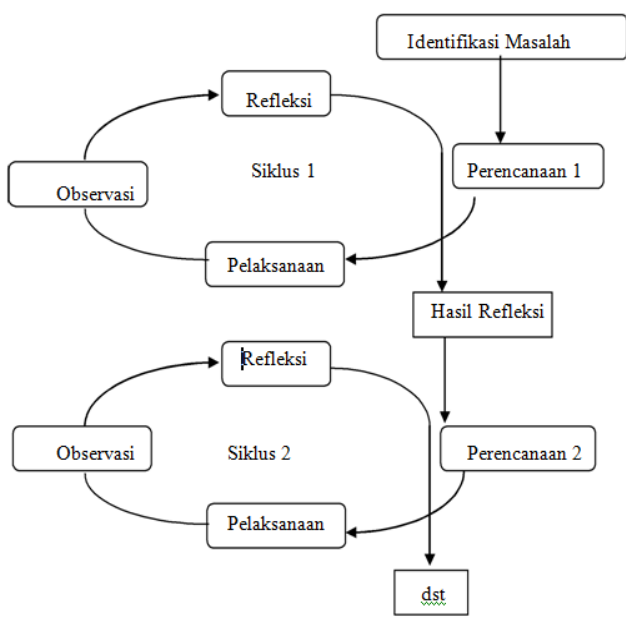

Gambar 3.1 : Siklus PTK Model

Kemmis dan McTaggart (Fitri Yuliawati dkk, 2012: 24)

Desain penelitian yang dipergunakan berbentuk siklus model Kemmis dan McTaggrat. Siklus ini tidak hanya berlangsung satu kali, tetapi beberapa kali hingga tercapai tujuan yang diharapkan. Desain penelitian ini adalah perencanaan, struktur dan strategi penelitian dalam rangka mengendalikan penyimpangan yang mungkin terjadi dan menjawab pertanyaan yang mungkin terjadi. a. Rencana (Planing)

Perencanaan adalah mengembangkan rencana tindakan yang secara kritis untuk meningkatkan apa yang telah terjadi. Rencana PTK hendaknya cukup fleksibel untuk dapat diadaptasikan dengan pengaruh yang tidak dapat diduga dan kendala yang belum kelihatan. Rencana PTK hendaknya disusun berdasarkan kepada hasil pengamatan awal yang reflektif. Peneliti hendaknya melakukan pengamatan awal terhadap situasi kelas dalam konteks situasi sekolah secara umum. Dari sini peneliti akan mendapatkan gambaran umum tentang masalah yang ada.

Hasil pengamatan awal terhadap proses yang terjadi dalam situasi yang ingin diperbaiki dituangkan dalam bentuk catatan-catatan lapangan lengkap yang menggambarkan dengan jelas cuplikan atau episode proses pembelajaran dalam situasi yang akan ditingkatkan atau diperbaiki. Kemudian catatan-catatan lapangan tersebut dicermati bersama untuk melihat masalah-masalah yang ada dan aspek-aspek apa yang perlu ditingkatkan untuk memcahkan 
masalah yang terjadi dalam proses belajar mengajar.

b. Tindakan (Acting)

Tindakan yang dimaksud di sini adalah tindakan yang dilakukan secara sadar dan terkendali, yang merupakan variasi praktik yang cermat dan bijaksana. Praktik diakui sebagai gagasan dalam tindakan dan tindakan itu digunakan sebagai pijakan bagi pengembangan tindakan-tindakan berikutnya, yaitu tindakan yang disertai niat untuk memperbaiki keadaan. PTK didasarkan atas pertimbangan teoritis dan empiris agar hasil yang diperoleh berupa peningkatan PBM optimal.

c. Observasi (Observing)

Observasi berfungsi untuk mendokumentasikan pengaruh tindakan terkait. Observasi perlu direncanakan dan juga didasarkan dengan keterbukaan pandangan dan pikiran serta bersifat responsif. Objek observasi adalah seluruh proses tindakan terkait, pengaruhnya (yang disengaja dan tidak disengaja), keadaan dan kendala tindakan direncanakan dan pengaruhnya, serta persoalan lain yang timbul dalam konteks terkait. Observasi dalam PTK adalah kegiatan pengumpulan data yang berupa proses kinerja PBM.

\section{d. Refleksi (Reflection)}

Refleksi adalah mengingat dan merenungkan suatu tindakan persis seperti yang telah dicatat dalam observasi. Refleksi berusaha memahami proses, masalah, persoalan, dan kendala yang nyata dalam tindakan strategis. Refleksi biasanya dibantu oleh diskusi di antara peneliti dan kolaborator. Melalui diskusi, refleksi memberikan dasar perbaikan rencana. Refleksi (perenungan) merupakan kegiatan analisis, interpretasi dan eksplanasi (penjelasan) terhadap semua informasi yang diperoleh dari observasi atas pelaksanaan tindakan.

\section{HASIL DAN PEMBAHASAN}

Sebelum melaksanakan penelitian pada siklus I, terlebih dahulu peneliti mencari data awal nilai keterampilan menulis pada pelajaran Bahasa Indonesia siswa kelas II SDN 3 Karangraja. Guna mengetahui ada tidaknya peningkatan keterampilan menulis pada siswa kelas II. Peneliti terlebih dahulu melakukan tindakan awal, yaitu melakukan observasi keterampilan menulis siswa tanpa menerapkan metode Direct Learning. 
Penelitian tahap awal dilakukan dengan tujuan untuk memperoleh data yang nantinya digunakan sebagai pembanding data penelitian yang diperoleh sesudah penerapan metode Direct Learning. Adapun hasil pada pra siklus dapat di lihat pada table berikut:

Tabel 4.1

Rekapitulasi hasil Pra siklus minat belajar siswa

\begin{tabular}{|c|l|c|c|}
\hline No & Pembelajaran & $\begin{array}{c}\text { Siswa yang Benar-benarTelah } \\
\text { Menunjukkan Yinat Belajar }\end{array}$ & $\begin{array}{c}\text { Presentase } \\
(\%)\end{array}$ \\
\hline 1 & Studi awal & 5 & 20,00 \\
\hline
\end{tabular}

Berdasarkan pada Tabel 4.1. Rekapitulasi hasil observasi minat belajar siswa dalam mengikuti pelaksanaan pembelajaran, diperoleh keterangan sebagai berikut :

a) Hasil studi awal diperoleh data untuk siswayang telah bersunguh-sungguh menujukan minat dalam belajar,minat belajar siswa ada 5 siswa, atau $(20,00 \%)$

b) Terdapat 20 siswa, atau $(80,00 \%)$ yang belum benarbenar dalam menujukan minat belajar, ini berarti masih rendah dan belum mencapai Ketuntasan.

Berkitan dengan adanya hasil pada pra siklus yang menunjukan masih rendahnya minat belajar siswa pada Bahasa Indonesia, maka peneliti bersama kolaborator sepakat untuk melakukan penelitian pada siklus I, adapun hasil pada siklus I dapat dilihat sebagai berikut:

Tabel 4.2

Rekapitulasi hasil observasi minat belajar siswa pada Siklus I

\begin{tabular}{|c|l|c|c|}
\hline No & Pembelajaran & $\begin{array}{c}\text { Siswa yang Benar- } \\
\text { benarTelah Menunjukkan } \\
\text { Minat Belajar }\end{array}$ & $\begin{array}{c}\text { Presentase } \\
\text { (\%) }\end{array}$ \\
\hline 1 & Studi awal & 5 & 20,00 \\
\hline 2 & Siklus I & 13 & 52,00 \\
\hline 3 & Kenaikan & 8 & 32,00 \\
\hline
\end{tabular}

Berdasarkan pada hasil Tabel 4.2 Rekapitulasi hasil observasi minat belajar siswa dalam mengikuti pelaksanaan pembelajaran, diperoleh keterangan sebagai berikut :

a) Pada studi awal, dari 25 siswa, hanya 5 siswa yang menunjukkan minat dalam belajar atau $(20,00 \%)$.

b) Pada Siklus I, siswa yang menunjukkan peningkatan minat dalam belajar meningkat menjadi 13 siswa atau $(52,00 \%)$.

c) Dari studi awal ke Siklus I, minat belajar siswa naik $(32,00 \%)$.

Proses pembelajaran yang telah di lakukan pada siklus I merupakan suatu acuan untuk memperoleh nilai dalam menentukan proses selanjutnya. Berkitan dengan adanya hasil pada siklus I yang menunjukan masih rendahnya minat belajar siswa pada 
Bahasa Indonesia, maka peneliti bersama kolaborator sepakat untuk melakukan penelitian pada siklus II, adapun hasil pada siklus II dapat dilihat sebagai berikut:

Tabel 4.3

Rekapitulasi hasil observasi minat belajar siswa pada Siklus II

\begin{tabular}{|c|l|c|c|}
\hline No & Pembelajaran & $\begin{array}{c}\text { Siswa yang Benar- } \\
\text { benarTelah Menunjukan } \\
\text { Minat belajar }\end{array}$ & Presentase \\
\hline 1 & Studi awal & 5 & 20,00 \\
\hline 2 & Siklus I & 13 & 52,00 \\
\hline 3 & Siklus II & 23 & 92,00 \\
\hline 4 & Kenaikan & 12 & 48,00 \\
\hline
\end{tabular}

Berdasarkan pada Tabel 4.3 Rekapitulasi hasil observasi minat belajar siswa dalam mengikuti pelaksanaan pembelajaran, diperoleh keterangan sebagai berikut:

a) Pada studi awal, dari 25 siswa, hanya 5 siswa yang menunjukkan peningkatan minat belajar atau $(20,00 \%)$.

b) Pada Siklus I, siswa yang menunjukkan peningkatan minat belajar meningkat menjadi 13 siswa atau $(52,00 \%)$.

c) Pada Siklus II, siswa yang menunjukkan peningkatan minat belajar meningkat menjadi 23 siswa atau $(92,00 \%)$.

d) Dari studi awal ke Siklus I, minat atau kesungguhan belajar naik $(32,00 \%)$, dan dari Siklus I ke Siklus II, minat atau kesungguhan belajar siswa naik $(40,00 \%)$.

\section{PEMBAHASAN}

Pada perbaikan pembelajaran pada mata pelajaran Bahasa Indonesia peneliti menggunakan model pembelajaran direct learning dengan lebih memberikan kesempatan siswa untuk lebih aktif. Ternyata dengan cara belajar yang demikian, mendapat respon yang sangat baik, dari hasil tes yang didapat di akhir pelajaran, $92 \%$ siswa sudah mendapat nilai 68 ke atas, meskipun masih ada 2 siswa yang mendapat nilai di bawah 68 .

Dari hasil pembelajaran yang dilakukan peneliti dari pembelajaran awal atau pra siklus sampai dengan perbaikan pembelajaran siklus II, maka peneliti berkesimpulan bahwa dengan menggunakan metode direct learning pada pelajaran Bahasa Indonesia materi menulis cerita dapat meningkatkan hasil belajar siswa kelas II di SD Negeri 3 Karangraja

Tabel 4.4 Perbandingan nilai dari Pra Siklus, Siklus 1, Siklus 2

\begin{tabular}{|l|c|c|c|}
\hline \multirow{2}{*}{ Catatan Prestasi } & \multicolumn{3}{|c|}{ Perolehan Xilai Siswa } \\
\cline { 2 - 4 } & Pra Siklus & Siklus 1 & Siklus 2 \\
\hline Nilai Terendah & 40 & 50 & 60 \\
\hline Nilai Tertinggi & 90 & 90 & 100 \\
\hline Jumlah & 1475 & 1715 & 2015 \\
\hline Rata-rata & 59,00 & 66,80 & 80,60 \\
\hline $\begin{array}{l}\text { Persentase Tuntas (\%) } \\
\text { Persentase Belum Tuntas } \\
\text { (\%) }\end{array}$ & $20,00 \%$ & $52,00 \%$ & $92,0 \%$ \\
\hline
\end{tabular}

Grafik 4.1 Presentase Perolehan nilai persiklus 


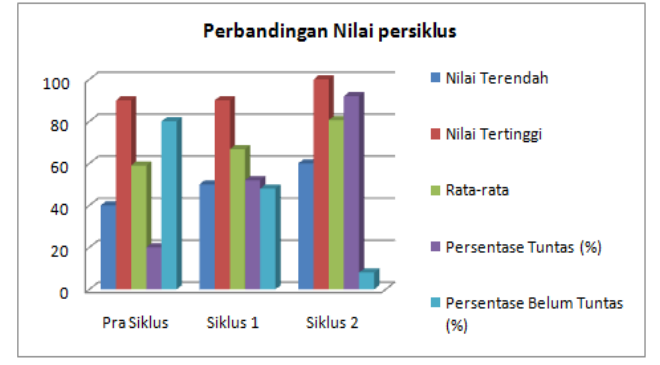

\section{KESIMPULAN}

Berdasarkan Penelitian Tindakan

Kelas (PTK) yang dilakukan pada kelas II di SDN 3 Karangraja dapat ditarik kesimpulan sebagai berikut:.

a. Melalui penggunaan metode direct learning pada mata pelajaran Bahasa Indonesia materi menulis cerita di kelas II dapat meningkatkan minat belajar siswa. Hal ini sesuai dengan pengamatan observer yang telah dilakukan pada siswa mulai dari pra siklus, kemudian siklus I sampai Siklus II dan terjadi peningkatan disetiap siklusnya yaitu dari pra siklus $20,00 \%$ meningkat $32,00 \%$ pada siklus I menjadi 52,00\% kemudian meningkat $40,00 \%$ pada siklus II menjadi $92,00 \%$.

b. Melalui penggunaan metode direct learning pada mata pelajaran bahasa Indonesia materi menulis cerita di kelas II dapat meningkatkan hasil belajar siswa. Hal ini sesuai dengan nilai hasil belajar yang diperoleh dari siklus I sampai siklus II, dimana nilai rata-rata siklus I 66,80 meningkat 13,80 point menjadi 80,60 pada siklus II.

\section{DAFTAR PUSTAKA}

Departemen Pendidikan Kebudayaan. (2007). Kurikulum Tingkat Satuan Pendidikan. Jakarta: Depdiknas.

Fitri Yuliawati, dkk. (2012). Penelitian Tindakan Kelas. Jakarta: Pusat Penerbitan Universitas Terbuka.

Irawan Soehartono. (2008). Metode penelitian sosial. Bandung: Remaja Rosdakarya.

Sukardi. (2004). Metodologi penelitian pendidikan. Jakarta: Bumi Aksara. 